\title{
KOMMUNIKÁCIÓS ÉS KAPCSOLATI TÉNYEZŐK JELENTŐSÉGE AZ EGÉSZSÉGÜGYI SZOLGÁLTATÁSOK MINŐSÉGÉBEN
}

A tanulmány célja, hogy egy szekunder kutatásra alapozva áttekintetést adjon az orvos-beteg kommunikáció elméleti hátteréról, a kommunikáció és az egészségügyi (pácienshez kapcsolódó) kimenetek közvetlen, valamint az együttmúködés és az észlelt minôség által összekötött közvetett kapcsolatáról. Ez azért fontos, mert a kapcsolat a kommunikáció és az objektíven mérhetố kimenetek (például egészségügyi állapot javulása) között - amelyeknek komoly gazdasági következményei is vannak - alátámasztja azt a feltételezést, hogy az orvos-beteg kommunikáció kutatására szükség van az egészségügy berkein kívül is. A felvázolt elméleti háttér segítségével pedig olyan modell kialakítása a cél, amely alapul szolgálhat egy késóbbi primer kutatásnak.

Kulcsszavak: egészségügyi szolgáltatások, orvos-beteg kapcsolat, kommunikáció

Az orvos-beteg kapcsolat a világ számos részén (fóképp a nyugati társadalmakban) jelentős változásokon ment keresztül az utóbbi években, évtizedekben - és ez a folyamat napjainkban is tart, természetesen eltérô fázisoknál az egyes kultúrákban, országokban. Gyógyítási szempontból eltolódás vehető észre a biomedikális modelltól (amelynek legfontosabb jellemzói a betegségek kizárólag biológiai okokra való visszavezetése, elidegenedett orvos-páciens kapcsolat, valamint orvos- és betegség-központúság) a bio-pszicho-szociális modell felé (ahol nemcsak biológiai, hanem társadalmi és pszichológiai tényezóket is figyelembe vesznek a betegségek okának keresésében és a terápiák tervezésénél). Ez azt jelenti, hogy az orvosoknak figyelembe kell venni ezt a több szempontú megközelítést, amikor mérlegelik a kezelési lehetôségeket, amely sokkal személyesebb kapcsolatot feltételez a pácienssel, amelyben mindkét fél személyisége, viselkedése és érzései is egyre inkább fontosak, ezáltal egyenrangú viszony alakulhat ki (Molnár - Csabai, 1994).

Változások tapasztalhatók ugyanakkor gazdasági és marketingszempontból is. A gazdasági szempontok elôtérbe kerülésének (többek között) az az oka, hogy az egészségügyi rendszerek még a fejlettebb országokban is finanszírozási problémákkal küzdenek, emiatt az egészségügyi dolgozók érdeklődése megnőtt a gazdasági és menedzsmenttudományok iránt, valamint költségtudatosságuk is erôsödött a korábbiakhoz képest (Málovics és tsai, 2007). Az egészségügyi ellátás egyre inkább szolgáltatásként jelenik meg, és ennek eredményeképp egyre nagyobb hangsúly kerül a marketingszempontokra, az igénybe vevői magatartásra és elégedettségre, a személyes kapcsolatmenedzsmentre, valamint a kockázatkommunikációra. Az egészségügyi szolgáltatás adott helyen és egyénnel, specifikus technológia alapján valósul meg, kimondott vagy nem kimondott elvárásokkal a háttérben, és általában nem ismételhető. Ennek eredményeképp fokozott jelentőséget nyer a szolgáltatási folyamatok kontrollja (Hajnal, 2005). Az egészségügy fejlődése egyre inkább széles körû́ választási lehetôségek, orvos és páciens között megosztott felelősség, valamint az egyének önmenedzselése felé halad (Sihota - Lennard, 2004).

A változások az egészségügyi ellátásokban valamennyi fenti szembontól az orvos-beteg kapcsolat és kommunikáció elmélete és gyakorlata fontosságának növekedéséhez vezetnek. A megfelelő kommunikációt, jó orvos-páciens kapcsolatot és a páciensek bevonását a terápiával kapcsolatos döntésekbe ugyanis egyre szélesebb körben tekintik olyan tényezóknek, amelyek 
elősegíthetik a gyógyulási/gyógyítási folyamat sikerességét és növelhetik a felek elégedettségét.

Fontos eleme mindennek a páciensek együttmúködési hajlandósága, amely nemcsak befolyásolhatja a kommunikációt, de annak következménye is lehet, és végsố soron az eredményességhez is hozzájárul. Az elégedettség, az ellátás minóségének észlelése és az együttmúködés olyan tényezók, amelyek hozzájárulhatnak az egészségügyi kimenetek javításához, segítve ezzel a páciensbiztonságot, csökkentve a visszaesések, kórházi felvételek, komolyabb beavatkozások számát (amelyeknek komoly gazdasági hozadékai is vannak). Ezért a folytonosan finanszírozási problémákkal küzdő egészségügyben érdemes részletesen foglalkozni ezzel a folyamattal. E tanulmány célja, hogy szekunder kutatásra alapozva áttekintést adjon az orvos-beteg kommunikáció elméleti hátteréról, a kommunikáció és az egészségügyi (pácienshez kapcsolódó) kimenetek közvetlen, valamint az együttmúködés és az észlelt minőség által összekötött közvetett kapcsolatáról. Ez azért fontos, mert a kapcsolat a kommunikáció és az objektíven mérhetô kimenetek (például egészségügyi állapot javulása) között - amelyeknek komoly gazdasági következményei is vannak - alátámasztja azt a feltételezést, hogy az orvos-beteg kommunikáció kutatására szükség van az egészségügy berkein kivüil is. A felvázolt elméleti háttér segítségével pedig olyan modell kialakítása a cél, amely alapul szolgálhat egy késóbbi primer kutatásnak.

\section{Az orvos-páciens kapcsolat és kommunikáció}

Az orvos és a beteg közötti kapcsolatot tekinthetjük olyan társas helyzetnek, ahol általában két fél (bár gyakran többen: hozzátartozók a beteg oldaláról, asszisztensek, vagy egyéb szakértók az orvos oldaláról) van jelen, és bármelyik fél jelenléte és tevékenysége hatással van a másikra. E tanulmányban a páciens szempontjából vizsgáljuk a helyzetet, ezért azt a hatást elemezzük, amelyet az orvos gyakorol a vele kapcsolatba lépett emberre. Ebból a szempontból nemcsak az orvos valóságos jelenléte fontos (az, ahogyan kinéz, amit mond, a stílusa, az, hogy érthetốn fogalmaz-e stb.), hanem a környezetben megjelenô implicit jelenléte is (a váróterem, a rendelő kinézete, tudományosságot, barátságosságot, intimitást sugall-e stb.) - mindezek befolyásolják a páciensek érzéseit, gondolatait, viselkedését.

Az utóbbi néhány évtizedben a változásoknak köszönhetôen az egészségüggyel foglalkozó tudományágak igen nagy figyelmet fordítottak az orvos-beteg közötti interakcióra, különösképpen a kommunikáció fontosságára és jellegzetességeire (Boon - Stewart, 1998; Kenny és tsai, 2009). Ennek elemzése azonban rendkívül nehéz, hiszen az orvos-beteg kapcsolat az egyik legkomplexebb interperszonális kapcsolat - olyan tulajdonságainak köszönhetően, mint az erőviszonyok kiegyenlítetlensége, az aszimmetrikus informáltság, az önkéntesség hiánya (hiszen az esetek többségében a szükség határozza meg az igénybevételét, nem pedig az, hogy valaki szeretné-e vagy sem ${ }^{1}$ ), létfontosságú, életbevágó kérdések és problémák felmerülése, ennek következtében pedig az erôteljes érzelmi érintettség (Ong és tsai, 1995). A közgazdasággal foglalkozó tudományágak ugyanakkor kevesebb figyelmet szenteltek e témakörnek, annak ellenére, hogy az egyre informáltabb, önállóan dönteni tudó és szándékozó ügyfelek fontos alanyaivá váltak a vizsgálódásoknak (Vick és tsai, 1998; saját keresés ${ }^{2}$ ). Természetesen ennek oka (a fenti sajátosságokon túl) az is lehet, hogy az egészségügyi szolgáltatásoknak mind kínálati, mind keresleti oldala eltér az üzleti alapon nyújtott és igénybe vett szolgáltatásokétól. Ahogyan Kornai (1998: 45.) megfogalmazza: „...széles körú az egyetértés abban, hogy az egészségügy markánsan különbözik a társadalmi tevékenységek más ágaitól.” Az ágazat sajátosságai kapcsán a szerzô az alábbiakra hívja fel a figyelmet:

- Mivel az egészségnek és életnek semmihez nem hasonlítható értéke van, a piac itt kudarcot vallhat, és rendkívül nehéz, illetve kérdéses a költségek és hasznok mérése.

- Nehéz meghatározni az „alapvető szükségletek” mértékét.

- Az egyedi érték miatt az emberek nagy része hajlandó specifikus egalitárius elveket elfogadni az egészségügyi szolgáltatások allokációjáról az egyenlő hozzáférés biztosítása morális elvvé válik. Emiatt károsnak tekintenének egy olyan folyamatot, melyben a biztosítás kizárólag piaci alapon múködne (ez ugyanis a biztosítási díjak emelkedéséhez, ezzel pedig egyre több ember kimaradásához vezetne).

- A kínálati oldal sokkal több információval rendelkezik a tranzakció tárgyáról, mint a keresleti oldal (információs aszimmetria). Részben ez az oka az orvos és beteg közötti kapcsolat aszimmetriájának is: az orvosnak, társadalmi rendszertól és gazdasági ösztönzóktól függetlenül hatalma van a beteg felett.

- Az egészségügyben hiánygazdaság uralkodik (e tulajdonságában párhuzamba állítható a többi ágazattal). Ennek következményei között a minőségi fejlesztés elhanyagolását, a vevớk kiszolgáltatottságát, egyes csoportok privilegizáltságát kell megemlítenünk. 


\section{Kommunikációs és döntéshozatali stílusok az egészségügyben}

A magyar származású Bálint az 1930-as években Londonban az orvos-beteg kapcsolat problémáival foglalkozó csoportokat hozott létre ${ }^{3}$, két évtizeddel késóbb pedig megszületett könyve, melyben az elhanyagolt, de vitathatatlan jelentôségú kapcsolati tényezóket elemzi (Csabai - Molnár, 1999). Szintén az 1950-es években Parsons, amerikai szociológus fogalmazta meg elsóként az orvos-beteg szerepek fogalmát és egymáshoz való viszonyukat, amelyet egyértelmúen aszimmetrikusnak tekintett: szerinte az orvos (a szakmai tekintélye által is erôsített) szituatív hatalommal rendelkezik betege felett, aki viszont függóségben van, de a betegséggel kapcsolatos felelősség alól teljesen felmentett (Morgan, 1997). E modellnek egyfajta kritikájaként tekinthetünk Szász és Hollender 1956-ban közzétett tanulmányára, amelyben dinamikusabbként mutatják be az orvos-beteg kapcsolatot, annak három típusát különböztetve meg:

- az aktivitás-passzivitás típusúnál valódi interakcióról tulajdonképpen nincs szó, hiszen olyan helyzetre vonatkozik, amikor a páciens nincs eszméleténél,

- az irányítás-kooperáció típusút tekintették normatív viselkedésnek: ekkor az orvos közli az utasításokat, a beteg feladata pedig, hogy engedelmeskedjen,

- a kölcsönös részvételt pedig mint ritka jelenséget írtak le, ahol egyenlók az erôviszonyok és elégedettség szükséges a kapcsolat folytatódásához (Molnár - Csabai, 1994).

Az elóbb leírt modell megismerése azért is érdekes, mert bár fél évszázaddal korábbról származik, igencsak ismerôs lehet napjaink gyakorlatában is. A korai tanul- mányok közül rendkívül figyelemre méltó még Byrne és Long modellje az 1970-es évekból, amelyet 2500 háziorvos-beteg találkozó történései alapján állítottak fel. Eredményeik szerint a konzultációk hat szakaszra bonthatók:

- kapcsolat kialakítása,

- a beteg jelentkezése okainak kiderítése,

- az orvos szóbeli és fizikai vizsgálatai,

- az orvos, vagy az orvos és a beteg, vagy a beteg - ebben a valószínúségi sorrendben - összegzik a problémát,

- az orvos, vagy az orvos és a beteg megtervezi a terápiát vagy a további vizsgálatokat,

- a konzultáció befejezése, általában az orvos által.

A szakaszok elemzésével a szerzók különböző konzultációs stílusokat tipizáltak, melyek az orvoscentrikus-betegcentrikus skálán helyezhetốk el; míg elôbbinél a cél a gyors információszerzés, amely alapján felállítják a diagnózist, és a páciensek részvétele kizárt, utóbbinál nagy hangsúlyt kap a páciens aktivitása, elvárásai, félelmei (Brown és tsai, 2006). Emellett azt állapították meg, hogy a konzultációs stílust leginkább az orvos saját tényezối határozták meg, és kevésbé voltak fontosak a betegre, valamint a helyzetre vonatkozó tényezók - „létezik tehát az egyes orvosokra jellemző, elsősorban az orvos viselkedése által meghatározott konzultációs stílus" (Molnár - Csabai, 1994: 82. o.). Jól illusztrálja ezen megállapítást az orvos-gyógyszer hasonlat, mely szerint az általános orvoslásban a legtöbbet használt orvosság maga az orvos, azaz nemcsak az a doboz gyógyszer számít, amit odaad a páciensnek, hanem az is, hogy hogyan adja - szükség van tehát ezen ,gyógyszer” gyógyszertanának leírására (Balint, 2000).

1. táblázat

Döntési stílusok és jellemzőik az orvos-beteg kommunikáció tükrében

\begin{tabular}{|l|c|c|c|}
\hline & Paternalista döntés & Közös döntés & Informatív döntés \\
\hline $\begin{array}{l}\text { Az } \text { információáramlás } \\
\text { iránya }\end{array}$ & $\begin{array}{c}\text { (nagyrészt) egyirányú } \\
\text { orvos } \rightarrow \text { beteg }\end{array}$ & $\begin{array}{c}\text { kétirányú } \\
\text { orvos } \leftrightarrow \text { beteg }\end{array}$ & $\begin{array}{c}\text { (nagyrészt) egyirányú } \\
\text { orvos } \rightarrow \text { beteg }\end{array}$ \\
\hline Az információ típusa & orvosi & orvosi és személyes & orvosi \\
\hline Az információ mennyisége & minimális & maximális (minden, ami releváns) & maximális (minden, ami releváns) \\
\hline $\begin{array}{l}\text { Ki mérlegeli az } \\
\text { információkat? }\end{array}$ & $\begin{array}{c}\text { az orvos } \\
\text { (esetleg más orvosokkal) }\end{array}$ & $\begin{array}{c}\text { az orvos és a páciens (esetleg másokat } \\
\text { is bevonva) }\end{array}$ & $\begin{array}{c}\text { az orvos és a páciens (esetleg } \\
\text { másokat is bevonva) }\end{array}$ \\
\hline Ki hozza meg $\boldsymbol{a}$ döntést? & az orvos & az orvos és a páciens, együtt & a páciens \\
\hline A páciens fö feladata & az előírtak pontos betartása & $\begin{array}{c}\text { információk nyújtása, preferenciák } \\
\text { kinyilvánítása, részvétel a döntésben }\end{array}$ & döntéshozatal \\
\hline Az orvos fö feladata & szakértó tanács adása, \\
döntéshozatal & $\begin{array}{c}\text { információk átadása, preferenciák } \\
\text { figyelembevétele, páciens bevonása a } \\
\text { döntésbe (az általa kívánt mértékben). }\end{array}$ & $\begin{array}{c}\text { minél teljesebb információ } \\
\text { nyújtása a lehetóségekról }\end{array}$ \\
\hline
\end{tabular}

Forrás: Brown és tsai (2006), valamint Elwyn és tsai (1999) alapján saját szerkesztés 
Ha a terápiával, illetve a további lépésekkel kapcsolatos döntések meghozatalának módját vizsgáljuk a kommunikáció alapján, azt találhatjuk, hogy az orvosközpontúság és a betegközpontúság itt is megjelenik. A témával foglalkozó irodalomban, eltéró elnevezésekkel ugyan, de alapvetôen háromféle döntéshozatali stílust különböztetnek meg (1. táblázat).

A paternalista döntéshozatal az orvosközpontú kommunikáció módszere; az orvos meghozza a döntést, amelyet közöl a beteggel. A közös döntés arra utal, hogy az orvos és a beteg közösen döntenek. E döntéshozatali módszert a nemzetközi szakirodalom SDM-nek (Shared Decision Making) nevezi, melyet a '90-es években fejlesztettek ki azzal a céllal, hogy a betegek elgondolásait és igényeit nagyobb mértékben figyelembe tudják venni az egészségükkel kapcsolatos döntéshozatalnál. Ennek eredményeképpen a betegek „önmenedzselése” nôhet, a felelősség is megosztottá válik, és a választási lehetôségek szélesebb köre merülhet fel egy-egy kérdésben (Sihota - Lennard, 2004). Az informatív döntéshozatal pedig azokat az eseteket írja le, amikor az orvos csak információkat nyújt, és a beteg hozza meg a döntést a terápiával kapcsolatban.

Természetesen fontos megjegyezni, hogy számos olyan helyzet van - például sürgósségi esetek -, amikor nincs lehetôség annak mérlegelésére, hogy hogyan történjen a döntéshozatal. Amikor viszont van lehetőség a döntésre, Klemperer (idézi Málovics és tsai, 2009) szerint a paternalista, illetve az informatív modellt kevés beteg igényli; többségük arra vágyik, hogy megfelelő információkkal ellátva az orvos bevonja ôt a döntési folyamatba. Ahogyan Elwyn (idézi de Haes, 2006) megállapítja, a közös döntés azon esetekben lehet megfelelő, amikor több lehetőség van, amelyeknek különbözó lehet ugyan a kimenete, de valamennyi kimenet körülbelül ugyanannyira megfeleló. Ugyanakkor fontos megemlíteni egy olyan eredményt is, mely szerint a páciensek paternalizmusra, illetve részvételre vonatkozó preferenciái nem feltétlenül zárják ki egymást (Ommen és tsai, 2008).

A kommunikáció és döntéshozatal módszereiról szóló szakirodalom kiterjedt volta és a politikákban világszerte megjelenő, betegeket bevonni kívánó törekvések ellenére azonban elmondható, hogy arról, hogy maguk a betegek milyen szerepet szánnak/szánnának maguknak az interakciókban, illetve hogy mik a valós igényeik, preferenciáik, kevés kutatás született (Thompson, 2007). Ahogy viszont a megvalósult kutatások eredménye is jelzi, nem biztos, hogy a ,shared decision" mindenáron történő alkalmazása megfelel a páciensek igényeinek (Langewitz és tsai, 2006; Little és tsai, 2001). Van olyan beteg, aki a paternalista vagy tekintélyelvú megközelítést - amelyet általában nem tartanak betegközpontúnak - tartja gondoskodónak (Epstein, 2006). Ezzel egyetértve úgy gondoljuk, hogy a páciens igényeit felmérve lenne ideális a kommunikáció és a döntési folyamat stílusát kialakítani.

\section{A kommunikáció szempontjából releváns egyéb tényezók}

Bár láttuk, hogy kutatási eredmények szerint az orvos saját stílusa nagymértékben befolyásolja a kapcsolat alakulását, számos olyan egyéb tényezố van, amelyekról fontos beszélni a kommunikáció kapcsán: az információs aszimmetria, a bizalom, az oktulajdonítás, a felek kommunikációs képességei, valamint az intézményi, kulturális és társadalmi szintû tényezókk.

A kapcsolatban betöltött szerepekból (is) adódik, hogy információs aszimmetria van az orvos és páciense között. Az orvos (kezdetben) nem ismeri a beteg preferenciáit arról, hogy milyen típusú kommunikáció volna a számára megfeleló, milyen előzetes tudással, tapasztalatokkal rendelkezik. A beteg pedig - laikus lévén nem tudja megítélni az orvos valós szakmai kompetenciáját, nem ismeri a betegségeket, kezelési formákat.

A bizalom az orvos-beteg kapcsolat kiemelkedően fontos összetevője. Az egészségügyi szolgáltatást vizsgálva e kérdéskör szinte elkerülhetetlen; számos szerzó állítja, hogy a bizalom az orvos-beteg kapcsolat, illetve közösség-egészségügyi intézmény kapcsolat egyik alapköve (lásd Calnan - Sanford, 2004; ChuWeininger - Balkrishnan, 2006; Rowe - Calnan, 2006). Erdem - Harrison-Walker (2006) szerint az orvos-beteg kapcsolat a kapcsolatok fontossági sorrendjét tekintve a második, egyedül a családi kapcsolatok előzik meg. A bizalom (egyik definíciója szerint) azt jelenti, hogy hiszünk abban, hogy valaki más, akitól függünk, nem fog olyan módon viselkedni, hogy az fájdalmas következményekkel járjon számunkra (Boon, idézi Fiske, 2006). Az orvos és a beteg közötti kapcsolat, bár talán egyre kisebb mértékben, de olyan viszony, amiben az orvos fölérendelt, a beteg alárendelt, függő viszonyban van, hiszen általában nem kompetens az adott témakört illetően. Az, hogy a beteg mennyire bízik meg az orvosában, nagymértékben befolyásolhat olyan tényezóket, mint például az együttmúködési hajlandóság - betartja-e a páciens a tanácsokat, kiváltja-e, beszedi-e a felírt gyógyszereket? A bizalmat megerôsítő kommunikáció különösen fontos olyan helyzetekben, amikor nemcsak fizikai, hanem pszichológiai vonatkozása is van az esetnek. Egy, a paternalista orvosi viselkedést a bizalom szempontjából vizsgáló kutatás megállapította, hogy a paternalizmus a beteg orvosba vetett bizalmához szignifikánsan kapcsolódik. Ugyanakkor felhívja 
a figyelmet arra, hogy bár vannak olyan orvosok, akik úgy gondolják, hogy a bizalom eléréséhez a kizárólagos út a paternalista orvosi stílus és a passzív viselkedés a beteg részéról, azonban ez a minta kevesebb (inkább az idősebb) beteg számára felel meg; a fiatalabb és jól informált páciensek inkább szeretnének részt venni a döntésben. Emellett a kutatásból az is kiderült, hogy vannak olyan tényezók, amelyek szorosabb kapcsolatban vannak a bizalom meglétével, mint a paternalista stílussal kapcsolatos preferenciák: ezek az érzelmi, illetve az információs (vagy kognitív) támogatás (Ommen és tsai, 2008). Az észlelt kockázat csökkentésében ugyancsak fontos tényezố a bizalom, hiszen minél jobban bízunk abban, aki a kockázattal kapcsolatosan kommunikál velünk, annál alacsonyabb lehet az észlelt kockázatunk (Slovic - Ropeik, 2003). Ugyanez vonatkozik a kontrollérzetre is, amely a sikeres beavatkozások egyik fontos tényezóje (Friedman - Silver, 2006).

Az attribúció, azaz oktulajdonítás fontos szerepet játszhat a páciensek döntéshozatallal kapcsolatos igényeinek megértésében. Abban az esetben, amikor a beteg a döntést, és ezzel a felelósséget teljes mértékben az orvosra bízza, hagyja, elképzelhetô, hogy szerepet játszik a külsố oktulajdonítás igénye - azaz, ha valami rosszul „sül el”, nem úgy sikerül a kezelés, ahogyan várták, akkor a sikertelenség felelősévé az orvos tehető, tehát a felelősséget és a belsố okokat elutasítva, rajta kívülálló okoknak tulajdonítja a páciens a kudarcot.

A kommunikációban természetesen a kommunikációs képességek is fontos szerepet játszanak. Esetünkben a páciensek ún. „health literacy”-je, melyet leginkább „egészségügyi írni-olvasni tudás”-ként fordíthatunk le. Meghatározása szerint ,az, amilyen mértékben az egyedi páciensek képesek alapvetô egészségügyi információk megszerzésére, feldolgozására és megértésére" (Hulsman és tsai, 2005: 223. o.). A kapott információk egyéni megértése és hasznosítása kiemelkedóen fontos - függetlenül attól, hogy a kommunikáció és a döntéshozatal milyen stílusban történt. (Ha paternalista stílusban, akkor a javaslatok betartásához, ha bevonásnál, akkor hogy érdemben tudjon részt venni a döntésben.)

Az egyéni jellemzók mögött természetesen társadalmi szinten érvényes jelenségeket is vizsgálhatunk. A félelmek kivédése és a kontrollérzet növelése érdekében egyre gyakrabban igénybe vett egészségügyi ellátás fokozott függóséget, az ellátóktól való kiszolgáltatottságot, csökkenó autonómiát, önmeghatározást eredményezhet. E folyamat során átalakul az egyén egészségképe, egészséghez való viszonya, felelőssége egészsége megőrzésében. Ekkor a „felelős” magatartás az ellátók által nyújtott szolgáltatás igénybevétele lehet, a függetlenség feladásáért cserében viszont az egyén a kockázatok minimalizálását, a felelősség átvállalását várja el (Füzesi - Lampek, 2007). Lényeges továbbá, hogy a más ágazatokban egyre inkább megszokott választási szabadság és fogyasztói információkeresés az egészségügyben kevésbé elfogadott: a saját véleménynyel és más forrásból származó információkkal érkezô pácienseket az orvosok „nyưgnek” tartják, és az alternatív lehetőségek felvetése is konfliktust okozhat.

\section{Együttmúködés}

Az együttmúködés (compliance) szerepe gyakran szerepel az orvos-beteg kapcsolattal és a gyógyítás sikerességével foglalkozó irodalomban témaként. Mivel a nem együttmúködő betegek aránya 20\%-tól akár $80 \%$-ig is terjedhet, és számos kimeneti tényezóre hatással lehet, kétségtelen, hogy ez a problematika releváns, és érdemes foglalkozni vele.

A szakirodalom alapján nem egyértelmú, hogy az együttmúködés fogalma (egészségügyi helyzetekben) hogyan határozható meg. Emellett különböző egészségügyi helyzetekben különböző megfogalmazásokkal találkozhatunk. Az Egészségügyi Világszervezet (World Health Organization, WHO) szerint az orvosi előírások betartása (adherence) arra vonatkozik, hogy ,,az egyén viselkedése - gyógyszerek szedése, diéta tartása és/ vagy életstílus-változások megvalósítása mennyiben követi az egészségügyi szolgáltató azon ajánlásait, amelyekben megegyeztek egymással" (Sabaté, 2003: 3. o.). Míg egyetértünk azzal a megállapítással, hogy a pácienseknek aktív partnerként kellene részt venniük a kezelésükkel kapcsolatos döntésben, és szükséges a megegyezés a két fél között; úgy gondoljuk, hogy az egészségügyi szolgáltató előírásainak való megfelelés olyan esetekben is fontos lehet, amikor nincsen elózetes megegyezés (pl. az orvos életstílus-változtatást írna elô, míg a páciens gyógyszert szeretne, vagy ha a felek nem értenek egyet a hagyományos és alternatív gyógymódok alkalmazásában). Ezért az együttmúködés kapcsán a WHO definícióját alkalmazzuk, de annak megegyezésre vonatkozó kitétele nélkül, és úgy gondoljuk, hogy az egyetértés az együttmúködés mértékének egyik fontos meghatározója. Az orvos-páciens együttmúködés többdimenziós jelenség, amelyet számos tényezố befolyásol.

A társadalmi és gazdasági tényezók (úgymint a szegénység mértéke, iskolázottság mértéke, a munkanélküliség, a gyógyszerek ára, a kultúra) nem minden kutatásban bizonyultak szignifikáns meghatározó tényezőnek - azt találták, hogy az adott ország fejlettségi szintjének csökkenésével növekszik ezen tényezók szerepe és úgy gondoljuk, hogy ez hazánkban is releváns lehet. Ezen gondolatot az OECD (2009: 16. o.) jelentése 
is alátámasztja: ,a magasabb nemzeti jövedelmet (egy fớre jutó GDP-ben mérve) általában összekapcsolják a magasabb születéskor váható élettartammal, azonban a nemzeti jövedelem magasabb szintjein ez a kapcsolat már kevésbé jelentoos". Ahogyan az 1. ábrán látható, hazánk nem tartozik ezen körbe, sốt Magyarországon a várható élettartam alacsonyabb, mint az a nemzeti jövedelem alapján várható lenne. Ugyanez a jelenség tapasztalható akkor is, ha nem a GDP, hanem az egy fốre jutó egészségügyi kiadás függvényében vizsgáljuk a várható élettartamot (OECD, 2009). Ezen tények természetesen nemcsak az együttmúködés, hanem a jelen tanulmányban vizsgált teljes témakör kapcsán is fontosak, hiszen azt is jelezhetik, hogy a társadalom egyészségügyi állapotát nem csak a pénzegységben mérhetô ráfordítások befolyásolják.

\section{A születéskor várható élettartam és az egy fớre jutó GDP kapcsolata}

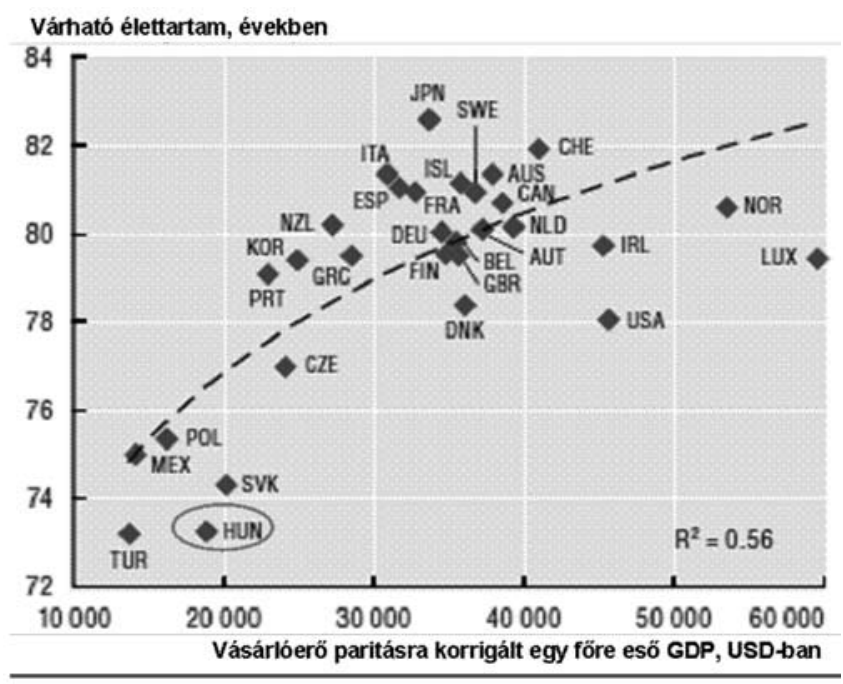

Forrás: OECD Health Data (2009)

Az egészségügyi rendszerre és gyógyító csapatra vonatkozó tényezókkel kapcsolatban (ide tartoznak az orvos és egyéb egészségügyi dolgozók tudása, kompetenciája, társas képességei csakúgy, mint esetleges túlterheltségük, motiváltságuk, teljesítményük és annak javadalmazása, kapacitásuk a beteg követésére, gondozására) kevés kutatás készült, ugyanakkor szintén nagyra becsülhetố a fontosságuk az együttmúködés kialakulásában/kialakításában. Az állapottal kapcsolatos tényezók a betegség által meghatározott, egyénhez kapcsolódó állapotokat takarják (pl. tünetek súlyossága), és hatásuk attól (is) függ, hogyan befolyásolják a páciens észlelt kockázatát és azt, mennyire tartják fontosnak a kezelésben elooírtak betartását. A terápiával kapcsolatos tényezók alatt az orvosi előírások komplexitását, a kezelés hosszát, esetleges korábbi sikertelenségeket, változtatásokat, a pozitív hatások azonnaliságát, valamint a mellékhatásokat érthetjük. A pácienshez kapcsolódó tényezók annak forrásait, tudását, attitúdjeit, hitét, észleléseit és elvárásait foglalják magukban (Sabaté, 2003). Molnár és Csabai (1994) szerint viszont a kutatások azt bizonyítják, hogy az együttmúködés mértéke egy konkrét esetben nem az állandó, személyiséghez köthetố tényezóktốl függ (ezek inkább általánosságban véve határozzák meg az egészséghez kapcsolódó viszonyt, illetve a saját egészségi állapot felett érzékelt kontrollt). Szerintük az orvos-beteg kapcsolat és az ezzel való elégedettség az együttmúködés legfontosabb meghatározója. Ezzel nagymértékig egyetértve, ugyanakkor a korábban felsorolt tényezők fontosságát is figyelemben tartva, a 2. ábrán láthatók azon tényezók, amelyek véleményünk szerint befolyásolják a páciens konkrét esetben tanúsított együttmúködését.

2. ábra

\section{Az együttmúköódés dimenziói}

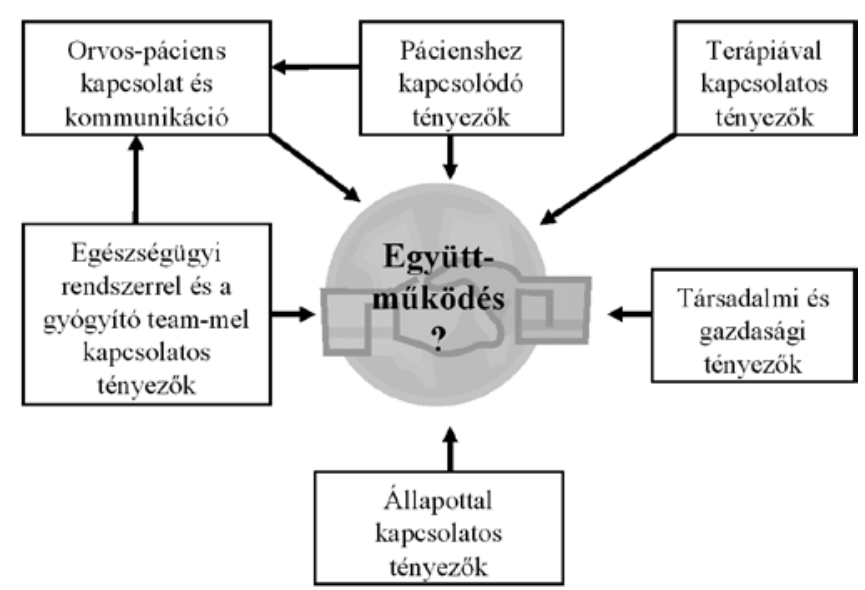

Forrás: saját szerkesztés Sabaté, WHO (2003) és Molnár és Csabai (1994) alapján

Nemcsak azt ismerték fel évtizedekkel ezelótt, hogy a páciensek gyakran nem követik az orvos által előírtakat (elsősorban a gyógyszerszedésre vonatkozóan, de más területeken is) (Paes és tsai, 1998), hanem azt is, hogy az együttmúködés mértékének mérése komoly módszertani akadályokba ütközik. Az együttmúködés mérésének számos módszere létezik, amelyek igen eltérő mértékeket állapítanak meg e jelenség kapcsán. Léteznek közvetlen mérések, mint például a megfigyelés, biológiai próbák és indikátorok használata, illetve közvetett módszerek, mint az interjúk, vagy a gyógyszerszemek megszámlálása - e módszerek közül egyik sem tökéletesen megbízható. Emellett pedig valószínúleg egészen különböző viselkedéseket mérnek. 
Ahogyan korábban említettük, a mért együttmúködés mértéke igen nagy skálán mozog; a WHO (Sabaté, 2003), illetve Young és Oppenheimer (2006) becslése szerint is a fejlett országokban a hosszan tartó terápiáknál az átlagos lakosság körében 50\% körüli az együttmúködés mértéke - a fejlődő országokban pedig ennél is alacsonyabb. Ez a megfogalmazás jelzi, hogy az együttmúködést mindig valamilyen specifikus helyzetre vonatkoztatva lehet mérni, illetve hogy igen magas az együttmúködés hiányának aránya, amely, ha figyelembe vesszük széles körú hatásait, igen figyelemre méltó.

\section{A kommunikáció egészségügyi kimenetekre gyakorolt hatása}

A kommunikációval kapcsolatos kutatások és fejlesztések szükségességének alátámasztásához szükség van annak vizsgálatára, hogy milyen mérhetố hatásai vannak. Az egészségügyi kommunikáció kutatásának talán legérdekesebb, ugyanakkor legkevésbé megértett területe a kommunikáció és az egészségügyi kimenetek közötti kapcsolatrendszer. Ezen összefüggések vizsgálata általában randomizált kontrollált kísérletekkel (RCT - randomized controlled trial) vagy leíró jellegú, keresztmetszeti elemzések útján történik. A kutatások a kommunikációs folyamat elemei változtatásának függvényében próbálják mérni a kimenetekben bekövetkezett változásokat. A téma vizsgálatakor természetesen elengedhetetlen definiálni, hogy milyen kimenetekról van szó: fizikai egészségi állapotokról (például fájdalom vagy egyéb tünetek jelenléte, különböző tesztek eredményei, testsúly) vagy pszichoszociális egészségi állapotról (amely azt jelzi, hogy az egyénnek mennyire pozitív vagy negatív gondolatai, érzései vannak, Street és tsai, 2009). Ezeket az állapotokat is - típustól függóen természetesen - lehet objektív eszközökkel mérni, vagy pedig a páciens észleléseire, beszámolójára támaszkodni. Vizsgálhatók még olyan kimenetek, mint a további kezelés igénybevételének mértéke, visszaesés, vagy épp az elégedettség (Di Blasi és tsai 2001).

A feltételezések szerint a kommunikáció közvetlenül vagy közvetetten is befolyásolhatja a kimeneteket. Nem egyértelmú ugyanakkor, hogy mit tekintünk végső kimenetnek, és mit köztes közvetítőnek - kiváló példa erre az elégedettség, mely mint kimenet szerepel számos tanulmányban, ugyanakkor közvetítóként is megjelenik. A 3. ábra szemlélteti az általunk felvázolt elméleti modellt a kommunikáció és a kimenetek lehetséges kapcsolatairól. Eszerint a(z orvosi) kommunikáció három eleme járulhat hozzá valamilyen módon az egészségügyi kimenetekhez, melyeken jelen esetben az objektíven mérhető tényezóket, fóképp a fizikai egészségi állapotot értjük ${ }^{4}$.
3. ábra

Az orvosi kommunikáció és az egészségügyi kimenetek összekapcsolódásai

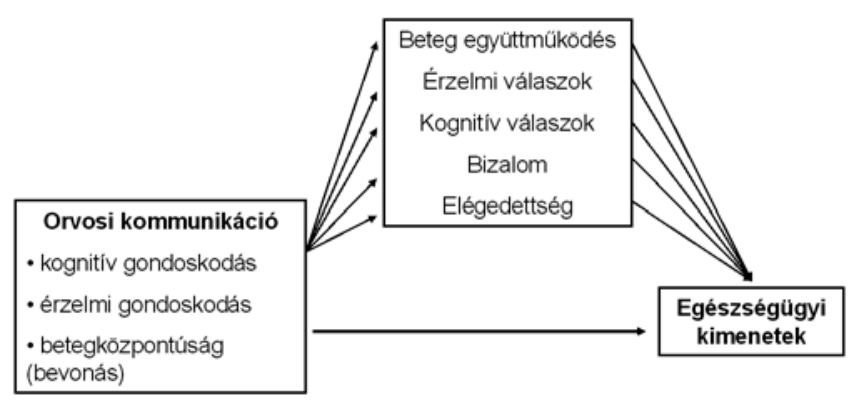

Forrás: saját szerkesztés Di Blasi és tsai (2001) és Street és tsai (2009) felhasználásával

A kognitív gondoskodás az orvos azon eszköze, amellyel befolyásolni tudja a beteg gondolatait a betegség vagy a kezelés hatásairól - például azzal, hogy optimista prognózist nyújt, vagy pozitív címkét ad az állapotnak. Ezzel befolyásolható a páciens betegségról, annak okáról és következményeirôl való gondolkodása, valamint a kezeléssel kapcsolatos elvárásai. Az érzelmi gondoskodás arra a viselkedésre utal, mellyel az orvos megpróbálja csökkenteni a „nem hasznos” érzelmeket, úgymint túlzott idegesség. Ugyancsak ide tartozik a támogatás, együttérzés, megnyugtatás. A kognitív és az érzelmi gondoskodás egymással összefonódva hatnak a páciensre ${ }^{5}$ (Di Blasi és tsai, 2001), feltételezésünk szerint párhuzamosan a betegközpontúsággal, azaz hogy az orvos a kommunikációs és döntési stílusok közül melyiket alkalmazza.

Bár a kommunikációt egyre szélesebb körben tekintik olyan tényezőnek, amely a konkrét terápia minôségétól függetlenül befolyásolja az egészségügyi állapotot, az empirikus vizsgálatok nem tudták ezt egyértelmúen alátámasztani. Számos kutatás talált szignifikáns kapcsolatot a kommunikáció egyes elemei és a kimenetek között (Little és tsai, 2001; Di Blasi és tsai, 2001), azonban olyan kutatások is vannak, melyek nem tudták ezt alátámasztani (Mead - Bower, 2002; di Blasi és tsai, 2001). Di Blasi és tsai (2001) a szaklapokban megjelent kísérletek értékelésekor ${ }^{6}$ azt találták, hogy az orvos-beteg kapcsolat valamely elemének változása körülbelül a vizsgálatok felében gyakorolt pozitív hatást a páciensek egészségügyi állapotára, és a leghatásosabb az volt, amikor a kognitív és érzelmi gondoskodás egyszerre volt jelen. Az általuk vizsgált kísérletek többsége a vérnyomást, illetve a fájdalmat vizsgálta mint kimeneti tényezô. A pozitív kapcsolatra szerintük jó példa Thomas kísérlete, amelyben azok a betegek, akiknél az orvos határozottan állapította meg a diagnózist és pozitív kilátásokat prognosztizált, szig- 
nifikánsan többen érezték magukat jobban (64\%), mint azok, akiknek azt mondták, hogy nem tudják biztosan, mi lehet a probléma (39\%). A kapcsolat hiányára pedig jó példa Van Weel kísérlete, melyben az azonos, mérsékelten magas vérnyomású páciensek egyik részével azt közölték, hogy ez rendben van, míg a többiekkel azt, hogy ez probléma, és kezelést igényel - a két csoport vérnyomása között azonban egy évvel késóbb nem észleltek különbséget. Tudomásul kell venni, hogy a kommunikáció hatásaira vonatkozó kutatásoknak számos korlátja és hiányossága van:

- igen széles skálán mozog az, hogy milyen egészségügyi kimeneteket mérnek (a vérnyomástól kezdve a páciensek észlelt aggodalmáig), emiatt összehasonlításuk meglehetősen nehéz,

- nem sikerült megmagyarázni, pontosan hogyan is kötődik a kommunikáció a kimenetekhez - a kutatások többsége korrelációt vizsgál, de ok-okozati kapcsolatra nem tud fényt deríteni,

- nem mindig egyértelmú, hogy a kommunikáció mely eleme kapcsolható mely kimenetekhez,

- gyakran elmarad az orvos-beteg kommunikáció tágabb környezetben való elhelyezése, így számos olyan tényező kimarad a vizsgálatból (például a hozzátartozók hatása), amellyel számolni kellene.

Mindezek miatt arra van szükség, hogy a kutatások a leíró jelleg helyett megpróbálják magyarázatát adni a kommunikációt kimenetekkel összekapcsoló utakra, figyelembe véve a szükséges környezeti hatásokat (Street és tsai, 2009; Epstein, 2006; di Blasi és tsai, 2001).

A fentiek miatt úgy gondoltuk, hogy érdemes az általunk egyik legfontosabbnak tartott közvetítő tényezôt - az orvosi kommunikációt - kiemelni és részletesebben megvizsgálni.

\section{A kommunikáció hatása az együttmúködésre}

Ahogyan fentebb említettuik, az orvos-beteg kapcsolat és kommunikáció és az ezekkel való elégedettség az egyuittmúködés egyik kulcsfontosságú tényezôje lehet (Molnár - Csabai, 1994). A Gfk LHS Healthcare (2007) közleménye szerint a mellérendelt kapcsolat és a terápiáról való közös döntés szükséges ahhoz, hogy a páciens a lehetô legjobban tudjon alkalmazkodni a kezelés követelményeihez, ugyanis ekkor rendelkezik a páciens a lehetô legtöbb információval. Ez a megállapítás azt sugallja, hogy a paternalista kommunikáció - mivel az átadott információk mennyiségét tekintve elmarad a másik stílustól - szükségszerúen lazább együttmúködéshez vezet. Míg egyetértünk azzal a gondolattal, hogy sok páciens számára a minél teljesebb informálás és a döntésbe való bevonás vezethet szorosabb együttmúködéshez, ugyan- akkor érdemes lehet átgondolni, hogy talán nem a minél teljesebb informálás, hanem a páciens igényeihez szabott informálás (ami akár paternalista stílushoz is kapcsolódhat) az, amely hozzájárul az együttmúködés magasabb szintjéhez. Természetesen figyelemre méltó az a hazai kísérleti eredmény, melyben egyhetes kezelésre szoruló betegeket vizsgáltak; a kontrollcsoportnak felírták a gyógyszert, elmondták a tudnivalókat, és egy hét múlva visszarendelték ôket, míg a kísérleti csoportban a felírást követő harmadik napon a nôvér telefonon érdeklődött a páciens hogylétéról és arról, szedi-e a gyógyszert. A követés végén igen figyelemreméltó volt az eredmény: a kontrollcsoportban 23,7 százalékos volt az együttmúködés mértéke, a másikban pedig 92,1 százalékban múködtek együtt a betegek a terapeutával (Gfk LHS Healthcare, 2007).

A kommunikációs folyamat fontos része a kockázattal kapcsolatos információk tálalása a páciens számára - ez arra utal, hogy milyen módon kapnak a páciensek információt a lehetséges mellékhatásokról, amelyek attól függóen következhetnek be, hogy milyen mértékben tartják be az orvos által előírtakat (nyilván a pontos betartás is rendelkezhet mellékhatásokkal, valamint a nembetartásnak is vannak következményei). Egy ebben a témában készuilt tanulmány szerint a mellékhatások valós, százalékban kifejezett esélyeirôl tájékoztatni a pácienst kevesebb félelmet és nagyobb mértékú együttmúködést eredményez, mintha csak általánosabb/elnagyoltabb kifejezéseket használnak (mint például: „néhány ember azt tapasztalhatja, hogy...", Young - Oppenheimer, 2006). Ezt a jelenséget magyarázhatja többek között a kilátáselmélet is, amely azt állítja, hogy az emberek hajlamosabbak túl nagy súlyt tulajdonítani valójában kis valószínúségekkel előforduló eseményeknek, és túl kis súlyt nagyobb valószínúségú eseményeknek, amely ahhoz vezethet, hogy egy nem általános eseményról azt gondolják, hogy sokkal gyakoribb, mint valójában. Emellett nemcsak a keretezés, azaz a probléma tálalása, hanem más hüvelykujjszabályok is befolyásolhatják az észlelt kockázatot: a reprezentativitás, az elérhetőség, vagy az attribúció. Mindezek mellett a kockázatot kommunikáló egyénbe vetett bizalom is nagymértékben fontos a kockázatészlelésben (Kahneman - Slovic - Tversky, 1982) - amely aztán hatással van az együttmúködésre.

\section{A kommunikáció hatása az észlelt minóségre}

Ahogyan Epstein (2006: 273. o.) megfogalmazta, ,a páciensek más dolgokat vesznek észre, mint az orvosok". Észreveszik, ha az orvos törődik velük, érdeklődô, figyelmes. Észreveszik a tiszteletet, a rugalmasságot, a megértést. Észreveszik, amikor az orvos hangja 
magabiztos, ugyanakkor érdekes, hogy a magabiztosságnak különbözô helyzetekben különböző értékeket tulajdonítanak. Észreveszik, ha az orvos megpróbálja kideríteni a fố problémát, és nem ragad le az elsô mondatnál. Észlelik tehát az orvos stílusát, de nemcsak az orvosét, hanem az asszisztensét és a portásét is.

Mivel az egészségügy egy (speciális) szolgáltatás, természetesen itt is érvényesül a minőség meghatározásának problematikája: egészen mást jelent a minőség a szolgáltatónak és az igénybe vevőnek, illetve mást egyik páciensnek, mint egy másiknak. Ebból adódóan először szükség van a szolgáltatást igénybe vevốk definiálására. Az egészségügyi szolgáltatás minden állampolgárt, végsố soron az egész társadalmat érinti, így mindenki potenciális fogyasztó (Hajnal, 2005). Azonban nem a beteg az egyetlen igénybe vevő: a 2. táblázat a lehetséges fogyasztókat, az egészségügy külső és belső vevôit, az általuk igénybe vett szolgáltatást és az azzal kapcsolatos elvárásokat jellemzi.
E tanulmány elsôsorban a betegekkel mint külsô vevő́kkel foglalkozik, az orvosokkal (mint belsố vevő́kkel) való kapcsolat kontextusában ${ }^{7}$.

A minőség tehát valamennyi igénybe vevô számára mást jelent. Általános és elvont értelemben azonban meghatározhatjuk úgy, mint a cél és az eredmény közötti elvárás (vagy másképpen fogalmazva, az elvárt és az észlelt helyzet távolsága); e definíció elfogadásával azonban nem zártuk ki a többféle értelmezés lehetôségét attól függóen, hogy ki határozza meg a célokat és ítéli meg a valódi értékét (Santiago és tsai, 2008). Az egészségügyi helyzetben ez egyértelmúen tetten érhető, hiszen nem mindegy, hogy az orvos mint szakértő, vagy a páciens mint a szolgáltatás ,,alanya”, sokszor kényszerú igénybe vevője határozza mindezt meg. Ebból adódik, hogy a szolgáltatások kétféle minőségét különböztethetjük meg: a technikai és a funkcionális minőséget. A technikai minóség egészségügyi környezetben a diagnózis és a végrehajtott eljárások technikai

2. táblázat

Vevốk és igényeik az egészségügyben

\begin{tabular}{|c|c|c|c|}
\hline & Vevö́ & Igénybe vett szolgáltatás & Elvárás/igény \\
\hline \multirow{9}{*}{ 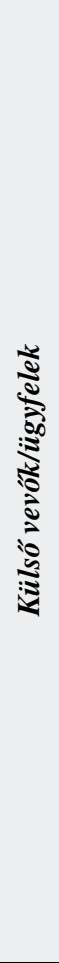 } & Egészséges ember & $\begin{array}{l}\text { Prevenció } \\
\text { Foglalkozás-egészségügyi ellátás }\end{array}$ & $\begin{array}{c}\text { Egészség megőrzése } \\
\text { Alkalmasság megállapítása }\end{array}$ \\
\hline & Beteg & $\begin{array}{l}\text { Alapellátás } \\
\text { Járóbeteg-szakellátás } \\
\text { Fekvőbeteg-ellátás } \\
\text { Mentőszolgálat }\end{array}$ & $\begin{array}{l}\text { Egészség helyreállítása } \\
\text { Állapot javítása/stabilizálása }\end{array}$ \\
\hline & Hozzátartozó & $\begin{array}{l}\text { Tanácsadás } \\
\text { Betegjogi képviselet } \\
\text { Hotelszolgáltatás } \\
\end{array}$ & $\begin{array}{c}\text { Hozzátartozójának megfeleló színvonalú } \\
\text { ellátása }\end{array}$ \\
\hline & Közösség/társadalom & $\begin{array}{c}\text { Szúrés } \\
\text { Prevenció } \\
\text { Területi ellátás } \\
\end{array}$ & $\begin{array}{l}\text { Morbiditás, mortalitás csökkentése } \\
\text { Igazságos ellátás }\end{array}$ \\
\hline & $\begin{array}{l}\text { Tulajdonos (pl. önkormányzat), } \\
\text { Fenntartó (pl. Kht.) }\end{array}$ & Vezetőség beszámolója & $\begin{array}{l}\text { Gazdaságos múködés } \\
\text { Presztízsnövekedés } \\
\text { Betegvonzás } \\
\end{array}$ \\
\hline & Finanszírozó (pl. OEP) & $\begin{array}{c}\text { A teljes szolgáltatás } \\
\text { Elszámolási adatszolgáltatás }\end{array}$ & $\begin{array}{c}\text { Előírt keretek betartása } \\
\text { Korrekt jelentés }\end{array}$ \\
\hline & Felügyelő (pl. ÁNTSZ) & Felülvizsgálat eltúrése & Törvényes és szakmailag korrekt múködés \\
\hline & $\begin{array}{l}\text { Más egészségügyi intézmény } \\
\text { (pl. szakkórház) }\end{array}$ & $\begin{array}{c}\text { Szakellátás } \\
\text { Diagnosztika }\end{array}$ & Kiegészítő vagy eltéró szolgáltatás \\
\hline & $\begin{array}{l}\text { Nem egészségügyi intézmény } \\
\text { (bármilyen szervezet) }\end{array}$ & Morbiditási szúrés & $\begin{array}{l}\text { Megelőzés } \\
\text { Felügyelet }\end{array}$ \\
\hline \multirow{3}{*}{ 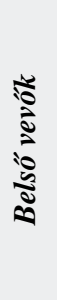 } & Munkatársak (pl. orvosok) & $\begin{array}{c}\text { Kiegészítő szolgáltatások } \\
\text { (pl. labor) }\end{array}$ & $\begin{array}{l}\text { A szolgáltatási igények gyors } \\
\text { és teljes körú kielégítése }\end{array}$ \\
\hline & Társosztályok/részlegek & $\begin{array}{l}\text { Konzílium } \\
\text { Ellátás }\end{array}$ & Azonnali és szakszerú intézkedések \\
\hline & $\begin{array}{c}\text { A szervezet területén múködő egészségügyi } \\
\text { szolgáltatók (pl. vállalkozó orvosok, laborató- } \\
\text { rium-üzemeltetôk) }\end{array}$ & $\begin{array}{l}\text { Kapcsolódó egészségügyi és } \\
\text { infrastrukturális intézkedések }\end{array}$ & $\begin{array}{l}\text { A teljesítési feltételek biztosítása, } \\
\text { zavartalan szakmai kooperáció }\end{array}$ \\
\hline
\end{tabular}

Forrás: Hajnal (2005) 
megfelelőségét jelenti. Az errôl szóló információ azonban az esetek többségében nem elérhetố a fogyasztó, azaz a páciens számára - a technikai minôség ismerete a szolgáltató hatáskörén belül marad. A funkcionális minóség arra a módra utal, ahogyan a szolgáltatást nyújtották a páciensnek - ez az a minőség, amely a betegek minőségértékelését elsődlegesen meghatározza (Babakus - Mangold, 1991). A mód, ahogyan a szolgáltatást közvetítették - tehát ahogyan az információkat megkapta a páciens, ahogyan eldöntötték, milyen kezelést kell alkalmazni, és hogy a páciens mennyire elégedett ezek megvalósulásával: a kommunikációt tekinthetjük a funkcionális minőség, és ezzel a beteg észlelt minőségének egyik alapvető meghatározójának. Az információs aszimmetria hatása érvényesül itt eróteljesen: a páciens, laikus lévén, nem tudja megítélni a technikai minőség milyenségét.

\section{Az együttmúködés szerepe és hatásai}

Az együttmúködés nemcsak egyéni szinten jár következményekkel, hanem társadalmi-gazdasági szinten is. A felírt gyógyszerek szedésével kapcsolatos előírások be nem tartása nem kívánt klinikai kimeneteket, valamint növekvő egészségügyi költségeket okoz. Az Egyesült Államokban évente 125.000 haláleset, a kórházi felvételek $10 \%$-a, illetve a gondozási központokba való felvételek 30\%-a elkerülhetô lenne, ha az emberek az elő́rtaknak megfelelóen szednék gyógyszereiket - mindennek költségét évente százmilliárd dollárra becsülik (Young - Openheimer, 2006). Emellett ezek a számok valószínúleg jóval magasabbak lennének, ha az együttmúködés hiányának más típusait is figyelembe vennénk (mint például a tanácsolt életstílus-változtatások elmaradását, amelyek aránya akár duplája is lehet a gyógyszerek nem szedéséhez viszonyítva - Molnár - Csabai, 1994 szerint), de természetesen ezek felmérése igen nagy nehézségekbe ütközik.

A terápiával kapcsolatos együttmúködés hiánya olyan költségeket von maga után, mint az új tünetek és rosszabbodó állapot megjelenésének és kezelésének költségei, vagy egy gyógyszer nem megfelelố szedésének mellékhatásait csökkentő újabb kezelés költségei. Mi több, egy gyógyszer megvásárlása, de aztán a beszedés elhagyása is költséget jelent csakúgy, mintha a páciens nem jelenik meg egy előre megbeszélt konzultáción - hiszen ez egy rést jelent az orvos időbeosztásán. Ha a nem beszedett gyógyszert meg sem vásárolják, vagy a találkozót meg sem szervezik, és az orvos foglalkozhat egy másik beteggel, a költségek csökkennek (ha nem lépnek fel komplikációk).

Tisztán gazdasági szempontból elemezve, a betegség súlyossága és a gyógyszer ára, vagy az orvos „lehetôségköltsége” határozza meg azt, hogy ezek a megtakarítások ellensúlyozni tudják-e a növekvő megbetegedések költségeit. Ahogyan a kommunikáció közvetlen hatásait, az együttmúködés hiányának költségeit is rendkívül nehéz mérni, hisz olyan módszertani problémákkal kell szembenézni, mint az együttmúködés mérése vagy a gazdasági értékelés szempontjainak meghatározása.

A költségek mérésére két módszert alkalmaznak az együttmúködés hatásait vizsgáló kutatások: a kórházi költségek figyelembevételét, valamint szélesebb körú költségek figyelembevételét. A kórházi költségek kiszámítása kétféleképpen történik: az együttmúködés hiányának tulajdonítható, kórházban eltöltött napok száma és az egy napra jutó kórházi költségek szorzata, vagy az irodalomból átvett együttmúködési ráta és az adott ország egészségügyi rendszerére vonatkozó aggregált költségadatok szorzata ${ }^{8}$ (Cleemput és tsai, 2002).

Kutatási eredmények szerint az együttmúködés magasabb foka nemcsak az egészségi állapotra lehet pozitív hatással, de gazdasági elónyökkel is járhat (közvetlen megtakarítások a betegségek súlyosbodása esetén szükséges kifinomultabb és drágább eljárások használatának csökkenése miatt, illetve közvetett megtakarítások, amelyek az életminőség megőrzéséhez vagy javulásához köthetốk). Az együttmúködés elősegítése javíthatja a betegbiztonságot a visszaesések számának csökkenése, függóség kialakulásának vagy a túladago-

4. ábra Az egészségügyi szolgáltatás-minôség kialakulásának folyamata

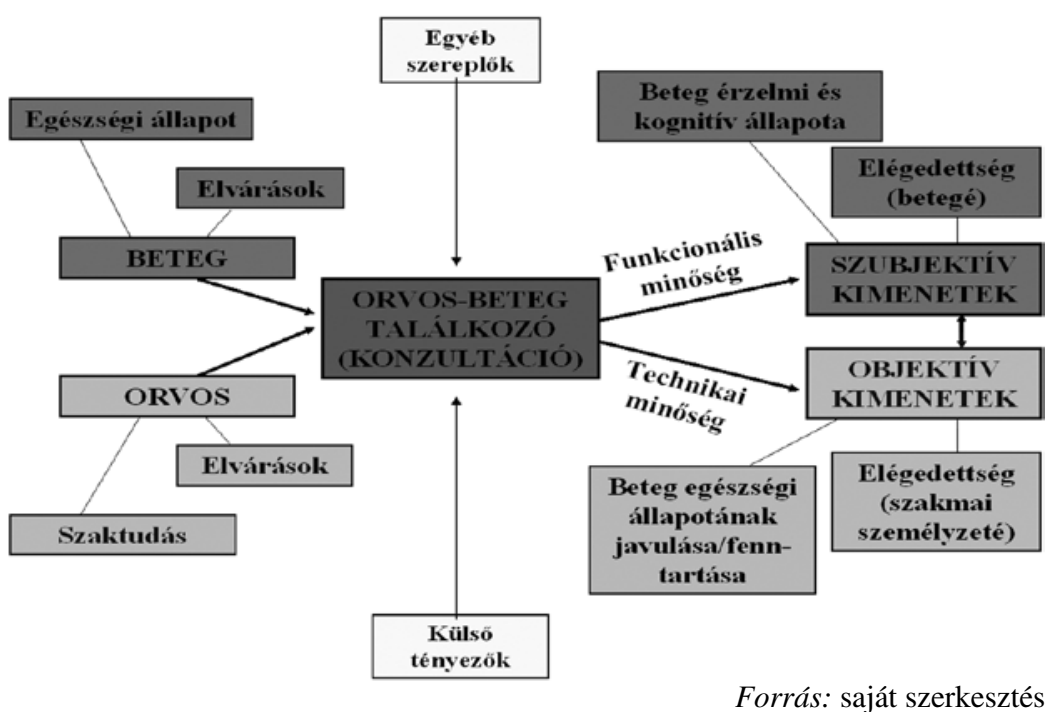


lás kisebb kockázata által. Mindemellett az együttmúködés javításának talán sokkal nagyobb hatása lehet a populációk egészségére, mint bármilyen fejlôdés a specifikus kezelések terén (Sabaté, WHO, 2003).

\section{Kutatási modell javaslat}

Az elméleti háttér feldolgozása alapján a javasolt elméleti és kutatási modellünk a szolgáltatásminôség alakulásának struktúrájába helyezi a részletesen vizsgálni kívánt eseményt: az orvosbeteg konzultációt és az azt befolyásoló tényezőket. A 4. ábra az egészségügyi szolgáltatás általunk vizsgált két szereplőjére vetítve ábrázolja a folyamatot.

A páciens a speciális egészségügyi állapota (problémája) mellett elvárásait hozza a találkozóra - mi az, amit a konzultációtól, az orvostól és az általa/általuk meghozott döntéstôl vár. Az orvos a maga szaktudásával fogad minden pácienst, és természetesen neki is vannak elvárásai a konzultációt illetôen mind a beteggel kapcsolatban (például hogy el tudja mondani, mi az oka a jövetelének), mind egyéb szereplő́kkel, többek között az intézménnyel szemben (például biztosítson megfelelő felszerelést, időbeosztást). Ezután megtörténik maga a konzultáció, melynek lefolyását nemcsak az elvárások, hanem számos más tényezó is befolyásol. (Természetesen, problémától függően, az elvárások és a konzultáció megtörténtének lépései többször ismétlődhetnek az ellátás folyamata alatt.) Ahogyan a minőségról szóló fejezetben szóltunk róla, a szolgáltatás sajátságaiból adódóan a két fél nem azonos módon határozza meg az ellátás minôségét. Az orvos képes megítélni a technikai minőséget, azaz szakmai szempontból értékelni a folyamatot (megtörténtek-e a megfelelố vizsgálatok, sikerült-e találni megfelelő gyógyszert, gyógymódot), míg a páciens a legtöbb esetben a funkcionális minôséget tudja megítélni - azaz, hogy hogyan, milyen kontextusban történt a gyógyítási folyamat. A funkcionális minőségkép kialakulásában igen nagy szerepe van a konzultáció milyenségének. Az észlelt (funkcionális) minőség befolyásolja ezután a szubjektív kimeneteket, azaz a beteg érzelmi és kognitív állapotát (mit gondol a betegségéról, a gyógyulási folyamatról), valamint az elégedettségét. A technikai minőség pedig az objektív kimenetekért, azaz az állapot változásáért felel. Természetesen az $o b$ jektív és a szubjektív kimenetek nem függetlenek egymástól - az orvos-beteg kapcsolatról és kommunikációról szóló kutatások és tanulmányok sokasága, ahogy láttuk, éppen arra igyekszik felhívni a figyelmet, hogy az objektív kimenetek nemcsak a technikai minóségtôl függnek, hanem (sokszor igen nagy mértékben) a funkcionális minőségen és szubjektív kimeneteken keresztül a konzultáció milyenségétól is. A folyamat e lépését mutatja be „nagyító alatt” az 5. ábra.

5. ábra

\section{Az orvos-beteg találkozó kommunikációját befolyásoló tényezôk}

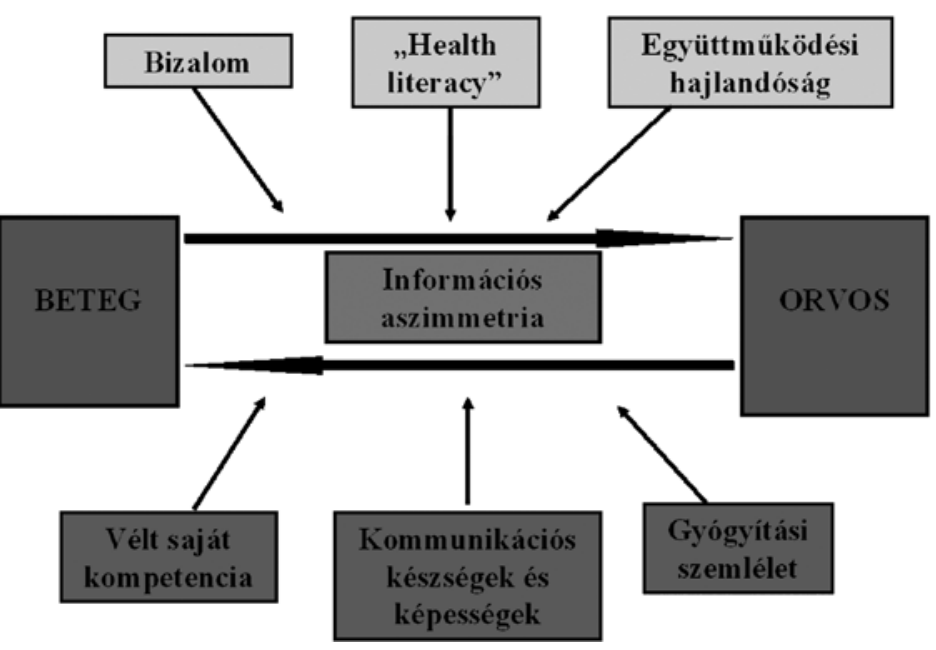

Forrás: saját szerkesztés

Az ábrán látható tényezók (melyek egy részérôl egy korábbi alfejezet szólt bővebben) a beteg vagy az orvos személyén keresztül befolyásolják a kommunikáció milyenségét. A két fél között információs aszimmetria van (tulajdonképpen ez az oka a technikai és funkcionális minôség szétválásának - a beteg nem tudja megítélni az orvos és az általa alkalmazott eszközök, módszerek valós szakmai minôségét). Azt, hogy a beteg hogyan kommunikál az orvossal, befolyásolja a bizalom - amelyet magát is számos tényező befolyásolhat, a korábbi tapasztalatokon, ismerôsöktől hallott történeteken és a médián túl az a tény is, hogy függőségi helyzetról van szó. A beteg az orvostól függ, annak szaktudásától, valamint attól, hogy kizárólag a segítségnyújtás-e a célja - ez pedig már az orvos gyógyítási szemléletével függ össze. Bizalomról azonban nemcsak az orvos személye kapcsán kell beszélni; fontos megemlíteni a rendszerszintú bizalmat is, azaz, hogy a páciens hogyan gondolkodik az ellátórendszerról. A bizalom kialakulásában fontos szerepet játszik a kommunikáció forrásának hitelessége (jelen esetben az orvos), a konzultációk gyakorisága, valamint, napjainkban egyre inkább, az internet szerepe (Erdem Harrison-Walker, 2006). A beteg kommunikációjában fontos lehet az egészségügyi írni-olvasni tudás, azaz, hogy a találkozón elhangzott, az egészségi állapotával és a lehetséges terápiákkal kapcsolatos információkat milyen mértékben és gyorsan tudja megérteni és hasz- 
nosítani. Lényeges továbbá az együttmúködési hajlandóság - erról a korábbiakban szintén volt szó.

Az orvos kommunikációját szintén számos tényező befolyásolja. Azonfelül, hogy mennyire magabiztos a saját tudásában és képességeiben, illetve hogy milyen magával hozott, valamint tanult kommunikációs képességei vannak, rendkívül fontos a gyógyítási szemlélete. Ezen elnevezés alatt az orvos-beteg kapcsolathoz és a döntési módszerekhez való hozzáállását értjük, azaz azt, hogy alapvetően betegközpontú, avagy orvosközpontú kommunikációt folytat, hogy mennyire igyekszik megteremteni a lehetôséget arra, hogy a beteg dönthessen a további lépésekról, illetve hogy milyen mértékben nyújt kognitív, illetve érzelmi gondoskodást. Ezek a tényezók természetesen (sok más egyébbel együtt) folyamatosan hatással lehetnek egymásra a beteg és az orvos interakciójában.

A fent bemutatott, egymásba épülő elméleti modellek alapján célunk olyan empirikus módszertant kialakítani, mellyel megvizsgálhatók a modellek részeit képezó konstruktumok és azok kölcsönhatásai, kifejezetten a hazai helyzetre vonatkoztatva.

\section{Összegzés}

Az orvos és beteg közötti együttmúködés fontosságának felismerése hozzájárult az orvos-beteg kapcsolat átalakulásához: ,,a hagyományos, tekintélyelvú, orvosi utasításokon alapuló kapcsolati modellt kezdi felváltani a partneri kapcsolat kialakítására törekvő, betegközpontú orvoslás modellje... a betegek elégedettségét (amely egyaránt meghatározója lehet az orvosválasztásnak, a terápiakövetô magatartásnak, de akár az orvosi perek arányának is) jelentôs részben az orvos-beteg kommunikáció határozza meg" (Pilling, 2004: 87. o.).

Ugyanakkor, bár elméleti szinten egyre szélesebb körben elismert a kommunikáció jelentősége, az empirikus kutatásoknak számos korlátja van, melyek kiküszöbölése megoldásra vár. Ezek közül, úgy gondoljuk, a legfontosabb az ok-okozati viszony feltárásának képessége. Míg a kommunikáció és a kimenetek közvetlen összekapcsolása nehézségekbe ütközik, az együttmúködés hatásainak értékelésére számos módszer és eredmény született. Mindez indokolja, hogy a témával továbbra is foglalkozzunk.

A páciensek igényeinek megfelelô stílus kialakítása, bár ideálisnak túnik, a gyakorlati megvalósítása igencsak nehéz lehet, köszönhetóen akár a kulturális vagy intézményi hagyományoknak, akár az orvosok túlterheltségének és az egyes páciensekre fordítható idő rövidségének - és annak, hogy igen nehéz valamennyi páciens egyéni igényét felmérni az adott keretek között.
A kutatási modell végső kialakítása után mind kvalitatív, mind kvantitatív módszerrel tervezzük megvizsgálni azt, hogy hazánkban milyen fontossággal bír a kommunikáció az orvos-beteg kapcsolatban: mélyinterjús módszerrel célunk a két fél, az orvosok, illetve az egészségügyben aktuális tapasztalatokkal rendelkező páciensek részletes véleményének feltérképezése a problémakörról, valamint a modell pontosítása, hogy ezután kérdőíves megkérdezéssel tudjuk felmérni az egészségügyi szolgáltatások minőségében fontos szerepet játszó tényezóket. Az eredmények alapján célunk javaslatokat tenni az ellátás minóségének javítása érdekében. Érdekes kitekintés lehet továbbá a közelmúltban tapasztalható influenzajárvány kapcsán kialakult helyzet orvosi kommunikációs szempontból történő elemzése is.

\section{Lábjegyzet}

${ }^{1}$ Bár erre vonatkozóan ellentétes kutatási eredmények is vannak, melyek szerint számos olyan eset van, amikor az orvos számára sem világos, hogy miért fordult hozzá a beteg, és számos esetben a beteg sincs tisztában azzal, hogy mit is vár a találkozástól (Málovics és tsai, 2009).

${ }^{2}$ A Journal of Health Economics-ban való kereséskor a „,communication” (kommunikáció), illetve a „relationship” (kapcsolat) szavak mindössze egy-két tanulmány címében jelennek meg.

${ }^{3}$ Ún. Bálint-csoportok napjainkban is múködnek; ezekben a csoportokban 8-10 általános orvos és egy-két pszichológus beszélik meg az orvos-beteg kapcsolatban felmerülő problémákat, a beteg érdekeit elótérbe állítva (Csabai és Molnár 1999).

${ }^{4}$ A kommunikáció páciens által befolyásolt vonatkozásait és a környezeti tényezóket ez a modell még nem foglalja magában, ez a modellalkotás egy következő lépcsőjében fog megvalósulni.

${ }^{5}$ Ezen tényezókroól a bizalommal foglalkozó alpontnál is volt szó, érzelmi, illetve információs támogatás elnevezés alatt.

${ }^{6}$ A szerzók olyan randomizált kontrollált kísérletek eredményeit értékelték, melyeket 183 keresôszó segítségével számos orvosi, pszichológiai és szociológiai adatbázisból választottak ki, és amelyekben valamilyen fizikai betegség kezelésében megjelenő orvos-beteg kapcsolat hatását vizsgálták.

${ }^{7}$ Természetesen a többi szereplő kutatásba való bevonása is érdemes volna, jelen keretek között azonban a két „f'ószereplő” viszonyára koncentrálunk.

${ }^{8}$ Ez utóbbi módszert áttekintve megpróbáltuk alkalmazni egy hazai példára. A Crohn-betegségre vonatkozó vizsgálat eredményei szerint a páciensek mintegy $20 \%$-a tekinthetô nem együttmúködőnek a kezelés szempontjából, ami jelen esetben a gyógyszerszedés elmaradását foglalja magában (Lakatos és tsai 2009). Hazánkban végzett felmérés szerint a megbetegedések száma 3,6/100.000 lakos/év. Ez azt jelenti, hogy hozzávetőleg 360 új páciens van évente. A betegség egy lehetséges kezelési módszere a TSO, mely gyógyszerszedésen alapul, és egy teljes kezelés költsége körülbelül 600000 Ft (www.crohn-colitis.hu). A számítást elvégezve, hazánkban a Crohn-betegségben megbetegedók nem együttmúködésének költsége egy évben $0,2 \times 360 \times 600000$ Ft, azaz 43,2 millió Ft, amely számottevő összeg, ha belegondolunk abba, milyen összeg lenne az eredmény, ha valamennyi előforduló betegségre ki tudnánk számítani ezt az összeget. 


\section{Felhasznált irodalom}

Babakus, E.-Mangold, W.G.(1992):Adapting the SERVQUAL Scale to Hospital Services: An Empirical Investigation. Health Services Research, 26/6, 767-786. o.

Balint, M. (2000): The doctor, his patient and the illness. Churchill Livingstone, London

Boon, H. - Stewart, M. (1998): Patient-physician communication assessment instruments: 1986 to 1996 in review. Patient Education and Counseling, 1998/35, 161-176. o.

Brown, B. - Crawford, P. - Carter, R. (2006): Evidencebased health communication. McGraw-Hill, London

Calnan, M.V. - Sanford, E. (2004): Public trust in health care: the system or the doctor? Quality and Safety in Healthcare, 2004/2, 92-97. o.

Chu-Weininger, M.Y.L. - Balkrishnan, R. (2006); Consumer satisfaction with primary care provider choice and associated trust. BMC Health Service Research, 2006/6, 34-42. o.

Cleemput, I. - Kesteloot, K. - DeGeest, S. (2002): A review of the literature on the economics of non-compliance. Room for methodological improvement. Health Policy, 2002/59, 65-94. o.

Csabai M. - Molnár P. (1999): Egészség, betegség, gyógyítás. Springer Orvosi Kiadó, Budapest

Di Blasi, Z. és tsai (2001): Influence of context effects on health outcomes: a systematic review. The Lancet, 2001/357: 757-762. o.

Epstein, R.M. (2006): Making communication research matter: What do patients notice, what do patients want, and what do patients need? Patient Education and Counseling, 2006/60, 272-278. o.

Erdem, S.A. - Harrison-Walker, L.J. (2006): The role of the Internet in physician-patient relationships: The issue of trust. Business Horizons, 2006/49, 387-393. o.

Fiske, S.T. (2006): Társas alapmotívumok. Osiris, Budapest

Friedman, H.S. - Silver, R.C. (2006): Foundations of Health Psychology. Oxford University Press, Oxford

Füzesi Zs. - Lampek K. (2007): Az egészségi állapothoz való viszony változásai. In: Kállai J., Varga J., Oláh A. (szerk.): Egészségpszichológia a gyakorlatban. Medicina, Budapest

Gfk LHS Healthcare (2007): Az orvos és a beteg együttmúködése fontos a terápia sikere céljából. Sajtóközlemény, 2007. 02. 07.

Hajnal M. P. (2005): Integrált irányítási rendszerek és modellek alkalmazási lehetôségei és buktatói az egészségügyben. IME, 2005/9, 30-36. o.

Hulsman, R. - Visser, A. - Makoul, G. (2005): Addressing some of the key questions about communication in healthcare. Patient Education and Counseling, 2005/58, 221-224. o.

Kahneman, D. - Slovic, P. - Tversky, A. (1982): Judgement under uncertainty: Heuristics and biases. Cambridge University Press, Cambridge
Kenny, D.A. és tsai (2009): Interpersonal perception in the context of doctor-patient relationships: A dyadic analysis of doctor-patient communication. Social Science and Medicine (2009), doi: 10.1016/j.socscimed. 2009. 10. 065.

Kornai J. (1998): Az egészségügy reformjáról. KJK, Budapest

OECD (2009): Health at a glance. OECD Indicators

Lakatos, P.L. (2009): Association of adherence to therapy and complementary and alternative medicine use with demographic factors and disease phenotype in patients with inflammatory bowel disease. doi:10.1016/j. physletb.2003.10.071.

Little, P. és tsai (2001): Observational study of effect of patient centeredness and positive approach on outcomes of general practice consultations. BMJ, 2001/323, 908911. o.

Málovics É. - Vajda B. - Kuba P. (2009): Paternalizmus vagy közös döntés? Páciensek az orvos-beteg kommunikációról. In: Hetesi E. - Lukovics M. (szerk.): A szolgáltatások világa, Szeged: JATEPress, 250-264. o.

Málovics É. - Veres Z. - Kuba P. (2007): Miért fontos a kockázat-kommunikáció az egészségügyben? Egészségügyi Gazdasági Szemle, 2007/2., 37-43. o.

Mead, N. - Bower, P. (2002): Patient-centered consultations and outcomes in primary care: a review of the literature. Patient Education and Counseling, 2002/48, 51-61. o.

Molnár P. - Csabai M. (1994): A gyógyítás pszichológiája. Springer Hungarica, Budapest

Morgan, M. (1997): The Doctor-Patient Relationship. in: Scambler, G. (szerk.): Sociology as Applied to Medicine. Saunders, London

Paes, A.H.P. - Bakker, A. - Soe-Agnie, C.J. (1998): Measurement of patient compliance. Pharmacy World \& Science, 20/2, 73-77. o.

Pilling J. (szerk., 2004): Orvosi kommunikáció. Medicina, Budapest

Rowe, R. - Calnan, M. (2006): Trust relations in health care - the new agenda. European Journal of Public Health, 2006/1, 4-6. o.

Ommen és tsai (2008): Trust, social support and patient type Associations between patients perceived trust, supportive communication and patients preferences in regard to paternalism, clarification and participation. Patient Education and Counseling, 2008/73, 196-204. o.

Ong, L.M.L. és tsai (1995): Doctor-patient communication: a review of the literature. Social Science \& Medicine, 40/7, 903-918. o.

Sabaté, E. (2003): Adherence to long-term therapies. World Health Organization, Switzerland

Santiago, P. és tsai (2008): A felsőoktatás a társadalomért. Az OECD tematikus áttekintése a felsôoktatásról: öszszefoglaló jelentés. Tempus Közalapítvány, Budapest

Sihota, S. - Lennard, L. (2004): Health Literacy. National Consumer Council, http://www.clingov.nscsha.nhs.uk/ Default.aspx?aid=1806. Letöltve 2007. 12. 10. 
Slovic, P. - Ropeik, D. (2003): Risk in perspective. Harvard Center for Risk Analysis, 2003/11.

Street, R.L. és tsai (2009): How does communication heal? Pathways linking clinician-patient communication to health outcomes. Patient Education and Counseling, 2009/74, 295-301. o.

Vick, S. - Scott, A. (1998): Agency in health care. Examining patients' preferences for attributes of the doctor-patient relationship. Journal of Health Economics, 1998/17, 587-605. o.
Young, S.D. - Oppenheimer, D.M. (2006): Different Methods of Presenting Risk Information and Their Influence on Medication Compliance Intentions: Results of Three Studies. Clinical Therapeutics, 28/1, 129-139. o. http://crohn-colitis.hu/hun/hirado-050701-tso2.php, letöltve: 2010. január 20.

Cikk beérkezett: 2010. 5. hó

Lektori vélemény alapján véglegesítve: 2011. 1. hó

\section{Szerzőinknek}

A Vezetéstudomány a Budapesti Corvinus Egyetem Gazdálkodástudományi Karának havi, referált folyóirata. A lapban a vezetési és gazdálkodási tudományterületekhez kapcsolódó témakörök elméleti és gyakorlati kérdéseit elemző és vizsgáló írások jelennek meg. A szerkesztőség (robert.becsky@uni-corvinus.hu) elektronikus formában kéri az írásokat.

A cikkeket elektronikus levélben (MS Word fájl formátumban) lehet a szerkesztőséghez eljuttatni. A Vezetéstudományban megjelent cikkek magyar és angol nyelvú összefoglalói elérhetőek a http://www.vezetestudomany.hu és a http://vezetestudomany.hu címeken.

A lap tudományos folyóirat, ezért szövegközi forráshivatkozások és ezek jegyzéke nélküli írásokat nem jelentet meg. A Vezetéstudományban megjelentetni szándékozott kéziratok szerzőitől az alábbi követelmények figyelembevételét kérjük:

- A cikkek szokásos terjedelme a hivatkozásokkal, ábrákkal és táblázatokkal együtt 20-24 oldal, 1,5-es sortávolsággal (12-es betüméret, Times New Roman betütípus).

- A cikkek első oldalának alján tüntessék fel a szerző foglalkozását, munkahelyét és beosztását, elektronikus levelezési címét, a tanulmány elkészítésével kapcsolatos információkat és az esetleges köszönetnyilvánításokat.

- A kézirathoz csatolandó egy magyar nyelvú és lehetőség szerint egy angol nyelvư rövid összefoglaló (200 szót nem meghaladó terjedelemben), valamint a cikk fő témaköreit megnevező kulcsszavak jegyzéke.

- Kiemeléshez félkövér és dólt betû használható, aláhúzás nem. Jegyzeteket lehetôleg ne használjanak, amennyiben azok feltétlenül szükségesek, szövegvégi jegyzetként adják meg.

- A táblázatoknak és ábráknak legyen sorszáma és címe, valamint - átvett forrás esetén - pontos hivatkozása.

- Az ábrákat és a táblázatokat a kézirat végén, külön oldalakon, sorszámmal és címmel ellátva kérjük csatolni, helyüket a szövegben egyértelmúen jelölve (pl. „Kérem az 1. táblázatot kb. itt elhelyezni!").
- A szövegközi bibliográfiai hivatkozásokat zárójelben, a vezetéknév és az évszám feltüntetésével kérjük jelölni: pl. (Veress, 1999); szó szerinti, idézőjeles hivatkozás esetén kiegészítve az oldal(ak) számával (pl. Prahalad - Hamel, 1990: 85.).

- Amennyiben egy hivatkozott szerzőnek több bibliográfiai tétele van ugyanazon évben, ezeket 1999a, 1999b stb. módon kell megkülönböztetni.

- A felhasznált források cikk végén elhelyezett jegyzékét ábécérendben kérjük, a következő formában:

1. példa (könyv): Porter, M.E. (1980): Competitive Strategy; New York: The Free Press

2. példa (folyóiratcikk): Prahalad, C.K. - Hamel, G. (1990): The Core Competence of the Corporation; Harvard Business Review, május-június, 79-91. o.

A formai követelmények fentiekben érvényesített, ún. „Harvard” rendszeréről (más néven „szerzólév” vagy „,név/dátum” hivatkozási módszerról) részletes tájékoztatást nyújtanak az alábbi WEB-címeken elérhető források.

Havi folyóirat lévén és a megjelenés átfutási idejének csökkentése érdekében a Vezetéstudomány kefelevonatot nem küld, elfogadás előtt azonban a szerzóknek egyeztetés céljából elküldi a cikk szerkesztett változatát.

2009. januártól a Vezetéstudományban publikált cikkek elérhetőek az ISI Eme „www.securities.com” internetcímen található strukturált on-line információs adatbázisban. 2009 júniusától a Vezetéstudományban közölt írások elérhetőek az EBSCO Academic Search Complete adatbázisában a http:// web.ebscohost.com/ehost/search vid $=20 \&$ hid $=102 \&$ sid $=747$ a 76 4f-362f-4683-9255-4e54f5ba0df7\%40sessionmgr 112 oldalon is.

Külön kívánságra 2004-ig visszamenóleg az összes korábbi kiadás publikációit elektronikus változatban is elküldjük.

Ha a szerző nem járul hozzá cikkének eseti kérésre, elektronikus úton való továbbadásához, kérjük, előre közölje ezt. 